\title{
Perkembangan Kepercayaan Mahasiswa dan Perilaku Belajarnya
}

\author{
Claartje Pattinama \\ Dosen Pastoral dan Psikologi pada Fakultas Teologi UKIM \\ e-mail: claartjepattinama33@gmail.com
}

\begin{abstract}
Abstrak
Kajian mengenai Perkembangan Kepercayaan Mahasiswa dan Perilaku Belajarnya, berangkat dari pengamatan penulis terhadap perkembangan kepercayaan mahasiswa yang didasarkan pada garis besar pandangan James $W$. Fowler dan pengamatan terhadap perilaku belajar mahasiswa pada Fakultas Teologi UKIM. Judul di atas hendak memperlihatkan hubungan antara psikologi agama dan psikologi pendidikan yang diamati pada mahasiswa Teologi. Kata Kunci: Perkembangan Kepercayaan, Perilaku Belajar, Mahasiswa Teologi.
\end{abstract}

\section{Perkembangan Kepercayaan Mahasiswa}

Dalam tulisan Fowler tidak dibahas tentang perkembangan, tetapi dijelaskan tentang kepercayaan remaja usia 18 tahun ke atas, usia yang demikian sama dengan usia mahasiswa umumnya . Menurut Fowler, pada usia 18 tahun sampai 20 tahunumumnya remaja mengalami suatu perubahan yang mendalam dan menyeluruh dalam hidupnya. Perkembangan ini sebelumnya ditentukan oleh perkembangan kepercayaan sebelumnya pada usia awal remaja yakni kepercayaan sintesis konvensional. Pada usia awal remaja fungsi dan tugas kepercayaan adalah mensintesis dan mengintegrasi bermacam-macam bayangan diri serta menjadikan satu kesatuan atau identitas yang koheren dan yan dapat berfungsi dengan baik. Di dalam sintesis identitas diri, berbagai bagian ego yang dipantulkan kembali oleh semua orang lain dalam bentuk bayangan diri, serta aneka pengalaman dan keterlibatan social, semuanya dipersatukan. Fowler menyebutkan tahap kepercayaan ini dengan istilah "sintesis" dimaksudkan bahwa beranekaragam isi dan keyakinan itu belum disatupadukan secara intrinsik-koheren. Artinya, semuanya itu belum dikaji secara kritis dan belum dipertanyakan apakah keanekaragaman tersebut secara intrinsic sungguh-sungguh cocok satu sama lain, sehingga dapat membentuk satu kesatuan yang menyeluruh dan selaras. 
Pada dasarnya visi global tersebut terutama diserap oleh orang-orang lain yang penting dan bisa dipercayai secara penuh. Identitas diri dibangun berdasarkan kesetiakawanan, kesetiaan dan kepercayaan kepada orang lain tersebut. Pola kepercayaan ini juga disebut "konvensional", sebab secara kognitif, afektif dan sosial seorang remaja menyesuaikan diri (conform) dengan orang lain yang penting baginya dan dengan mayoritas orang. Kepercayaan seperti ini belum diperjuangkan dan diasimilasikan secara kritis dengan daya percaya pribadi. Remaja belum dapat mengandalkan perasaan dan pendapat pribadi, belum mandiri, masih labil dan agak kacau. Kewibawaan dan kekuasaan ditempatkan diantara "orang-orang lain", semua ini memainkan peranan dalam pergeseran yang terjadi pada gambarannya tentang Allah. Allah dipandang menurut model "kepribadian dan sifat "pribadi", yaitu Pribadi Lain yang penuh misteri dan daya pesona. Pribadi Lain yang ilahi ini sangat penting bagi pribadi remaja. Karena Dialah yang menopang seluruh daya upaya hidup remaja.

Selanjutnya menurut Fowler perubahan mendalam dan menyeluruh, yakni pertama struktur berpikir masa dewasa awal yakni pada usia 18 sampai 20 tahun, atau dewasa muda, mereka tidak lagi memiliki pola berpikir sintesis-konvensional. Struktur berpikir operasional formal kini diperolehnya secara penuh. Hal ini berarti bahwa pada tahap ini, muncul suatu kesadaran jelas tentang identitas diri yang khas dan otonomi tersendiri, diperjuangkan suatu jenis kemandirian baru, singkatnya kesadaran diri dan refleksi diri yang mendalam. Orang dewasa muda semakin tajam melihat perbedaan antara sekian banyak diri yang dipersepsikan oleh orang lain dari luar dan jati diri asli yang "hanya dapat dirasakan oleh dirinya sendiri" Dengan demikian refleksi diri tidak tidak seluruhnya bergantung pada orang lain.

Kedua, orang dewasa muda mulai mengajukan pertanyaan kritis mengenai keseluruhan nilai, pandangan hidup, keyakinan kepercayaan, dan komitmen yang sampai pada saat itu bersifat tidak diucapkan serta diterima sebagai benar dan sah secara konvensional-konsensus berdasarkan autoritas ekstern. Semua mulai diperiksa secara kritis dan "objektif" berdasarkan keabsahan bagi manusia. Kekuasaan dan autoritas sebelumnya ditempatkan di luar dirinya sendiri, kini bukan hanya dinteriorisasikan ke dalam kepribadiannya, melainkan diletakkan pada dirinya sendiri sebagai sumber autoritas bathin. 
Ketiga, orang dewasa muda sendirilah harus memikul tugas menentukan pilihan dan menyingkirkan sekian banyak alternatif lain menyangkut komitmen dalam hidup dan kepercayaan yang terbuka baginya. Ia tidak dapt bersandar lagi pada orang lain, tetapi dengan berani dan kritis ia sendiri harus memikul tanggungjawab mengadakan pilihan pribadi secara eksplisit mengenai ideologinya(suatu kesatuan ide-ide dan nilai-nilai penuntun yang koheren), filsafat dan cara hidup yang membuka jalan bagi komitmen-komitmen kritis dan penuh mawas diri dalam segala hubungan dan tugasnya. Pada tahap ini, orang dewasa muda sungguh-sungguh tanggap dan peka terhadap segala macam pimpinan ideologis dan karismatis.

Keempat, perubahan menyangkut pandangan dan sikapnya terhadap orang lain dan kelompok. Orang dewasa muda kini memahami dirinya dan orang lain tidak hanya menurut pola sifat "pribadi" atau "antar pribadi" melainkan juga sebagai bagian dari suatu sistim sosial dan institusional. Keanggotaannya dalam suatu kelompok tidak lagi hanya mengambil alih tridisi yang tidak direfleksikan dan dipilihnya sendiri, melainkan dipilih sendiri dan disahkan kembali menurut pengertian kritis bahwa kelompok semacam itu mencerminkan identitas diri autentik secara paling baik dan tepat.

Pada semua perkembangan yang disebutkan di atas merupakan ciri khas, daya kuasanya sendiri yang baru dirasakan, (saya berpikir, melakukan ini dan itu, sayalah yang memilih) begitu kuat sehingga istilah "pengontrolan" (sadar dengan sengaja) boleh dipandang sebagai tujuan tahap ini, sedang "sistim" (baik yang kognitif-ideologi maupun yang sosial-institusiona) merupakan metaphor generatifnya. Selanjutnya tahap ini menghasilkan sikap kritis terhadap seluruh symbol, mitos dan sebagainya, sehingga dengan tepat boleh disebut tahap “demitologisasi”. Segala macam symbol dan mitos mulai diperiksa atau diselidiki secara radikalkritis. Hal ini berarti bahwa tanda atau symbol tidak lagi dipandang identik dengan isi sakral yang dilambangkan, melainkan sebagai sarana ekstern yang secara kurang memadai memuat sejumlah arti yang secara kritis hendak dialihkan ke dalam pengertian rasional yang dirumuskan dengan bahasa konseptual yang abstrak dan umum.

Kepercayaan pada tahap ini ditandai dengan kesadaran tajam akan individualitas dan otonomi. Hanya apa yang dipandang "tepat" dan "benar" yang berlaku bagi dirinya. Pengalaman pribadi, cita rasa nilai, dan pertimbangan kritis pribadi yang bersumber pada ego atau "subjek 
diri"eksekutif dan autoritatif kini menjadi kriteria paling akhir dan sumber acuan paling tinggi. Kalau ia mengakui autoritas religious pada pribadi tertentu misalnya Yesus, maka pengakuan itu dilakukan bukan karena ia secara diam-diam menyamakan diri dengan tokoh yang oleh tradisi religious Kristen berdasarkan kesepakatan bersama diumumkan dan disahkan sebagai pendiri agama yang genius atau nabi religious paling utama, melainkan karena pribadi istimewa tersebut dipandang sebagai pribadi yang sungguh-sungguh menghayati hubungan kesatuan utuh dengan Allah. Kini bagi orang dewasa muda, yang dijadikan kriteria adalah aspek penghayatan yang sungguh-sungguh pribadi, sebagaimana diilhami dan disemangati oleh Allah yang berkarya dan mendorong hati mereka.

Gambaran orang dewasa muda mengenai Allah pun memperlihatkan unsur-unsur individuatif-reflektif dan kritis-rasional itu. Dengan sikap kritis, ia mencari dan menyusun suatu gambaran tentang Allah yang dapat dipertanggungjawabkan secara pribadi dan rasional, sehingga gambaran tersebut tidak mungkin dikaburkan oleh berbagai aspek naïf yang belum pernah dipertanyakan. Di sini kritik terhadap agama berupa pembongkaran ilusi palsu dan demitologisasi terhadap gambaran Allah yang naïf dan primitif mendapat tempat yang wajar dan penting. Dengan sikap kecurigaan kritis bermacam-macam symbol tentang Allah diperiksa,

Sesuai dengan kecenderungan individuatifnya, kini agaknya Allah dicari dalam diri pribadi sendiri dan dikaitkan dengan ego eksekutif yang bersumber pada autoritasnya sendiri. Allah bukan pengurus atau pembantu, tetapi bagaikan Sang Pendukung dan Pendorong bathin, memberi semangat pada ego mandiri yang harus menjadi perancang dan pelaku hidupnya sendiri. Namun titik lemah pada tahap kepercayaan ini, salah satunya secara berlebihan orang dewasa muda mengandalkan kekuatan dan daya akal budi kritis yang dianggapnya bisa menguasai dan mengendalikan segalanya dalam genggaman rasional dan tidak akan membiarkan sesuatu barangpun dalam kegelapan tanpa ditembusi oleh sinar akal budi. Dengan demikian orang dewasa muda menekankan kesadaran aslinya akan faksitas, ketergantungan, kerapuhan, dan ketakberdayaan rasio itu sendiri, sebab rasio memang takkan pernah sanggup menangkap seluruh kekayaan dan kedalaman misteri pengalaman eksistensial prareflektif. Tidaklah mungkin untuk secara tuntas dan memadai mengerti dan menyerap kelimpahan arti pengalaman tersebut dengan mengalihkan ke dalam bahasa konsep yang serba transparan. 


\section{Perilaku Belajar Mahasiswa.}

Dari pengamatan, ada mahasiswa yang benar-benar berusaha mengejar tujuan belajar mereka di Fakultas. Hal itu nampak dari persiapan mereka menghadapi setiap materi kuliah, juga kegiatan kerja mereka dalam rangka menyelesaikan tugas-tugas kuliah yang diberikan setiap dosen. Mahasiswa yang demikian, dapat dikatakan sebagai orang-orang yang memiliki motivasi kuat berasal dari dalam dirinya, yang merangsang perilaku membentuk pengaruh dan kepercayaan dalam diri untuk mencapai harapannya. Hal serupa yang diungkapkan Schunk dkk (2008) bahwa motivasi sebagai proses yang mendorong dan memperkuat aktifitas menuju tujuan, jadi motivasi membutuhkan aktifitas mental dan fisik. Bagi mahasiswa yang memiliki motivasi kuat, tidak ada alasan untuk tidak belajar atau mengerjakan tugas, sekalipun lebih dari dua (2) atau tiga (3) tugas sehari.

Berbeda dengan mahasiswa yang selalu mencari alasan untuk menghindari tugas-tugas belajar, atau tidak mempersiapkan diri menghadapi kuliah. Mahasiswa seperti ini dapat dikatakan sebagai orang-orang yang tidak memiliki motivasi jelas untuk mengikuti pendidikan di Fakultas Teologi. Mereka ini hanya mau dilihat atau dikenal orang lain sebagai mahasiswa. Menurut Cote dan Levine (1977), mereka yang tidak memiliki motivasi kuat dan jelas, menandakan bahwa mereka tidak memiliki alasan mengapa dan untuk apa menjadi mahasiswa pada sebuah Universitas atau Fakultas. Mereka ini umumnya menyelesaikan masa studinya dalam kurun waktu yang cukup lama, 6 tahun lebih atau 7 tahun (14 semester). Penyelesaian study mereka itupun kalau mereka mendapat dorongan dari orang tua, saudara juga para dosennya. Jika kesadaran dan motivasinya tidak dibangkitkan dari luar dirinya, mereka tidak berhasil dalam studi. Berbeda dengan mahasiswa yang memiliki motivasi kuat untuk mencapai tujuan, mereka dapat menyelesaikan studinya dalam kurun waktu yang tidak lama, ada yang menyelesaikan studi Stratal tepat 4 tahun.

Penyelesaian studi yang tepat waktu terjadi jika mereka mendapat dukungan penuh dari orang-tua dan saudara-saudaranya, juga dosen tutor atau penasehat akademiknya. Bukan saja dukungan semangat dan emosional, tetapi juga dukungan informasi dan finansial. Hal ini memperkuat rasa percaya diri mereka sebagai mahasiswa yang berhasil, karena dikasihi orangtua, saudara dan para dosennya. Ada mahasiswa yang memiliki motivasi kuat untuk belajar dan 
mengerjakan tugas-tugas kuliah, tapi kadang menghadapi tantangan kurang beaya dari orang-tua, juga kurangnya sumber beasiswa. Hal ini tidak mengendorkan semangatnya untuk mencapai tujuan penyelesaian studi, sekalipun tidak sama dengan mahasiswa yang didukung penuh secara finansial dari orang-tua. Mahasiswa yang memiliki motivasi kuat untuk menyelesaikan studi, tetapi terkendala dukungan beaya dari orang-tua, mendorongnya untuk membiayai diri sendiri dengan bekerja. Ada yang bekerja sebagai tukang sapu jalan, sebagai pengangkut sampah, ada juga yang berjualan sayur di pasar, tapi ada juga bekerja mencuci dan menggosok/menyetrika pakaian pada keluarga-keluarga tertentu. Pekerja apapun yang dilakukan yang terpenting baginya adalah pekerjaan yang baik dapat menghasilkan uang untuk menunjang penyelesaian studinya. Bagi mahasiswa seperti ini, percaya bahwa Allah yang diyakininya sebagai Allah yang berkarya mendorong dirinya mengatasi semua tantangan yang dihadapi demi mencapai tujuan atau citacitanya. Dengan kata lain percaya kepada Tuhan mendorongnya untuk berusaha atau bekerja apapun yang baik demi penyelesaian studinya.

Mahasiswa yang memiliki motivasi kuat, umumnya memiliki komitmen untuk menjaga perilaku yang baik dalam belajar, maupun memenuhi peraturan yang berlaku di Fakultas. Tidak disangkali bahwa ada mahasiswa yang memiliki kecerdasan intelektual atau kognititifnya yang baik, tapi kadang tidak komitmen terhadap peraturan. Katakanlah mereka melakukan perbuatan melanggar aturan Fakultas. Jadi mahasiswa seperti ini dapat dikategorikan sebagai orang yang perkembangan kecerdasannya kognitif atau intelektualnya tidak seimbang dengan kecerdasan sosial dan emosionalnya. Kestabilan kepribadiannya belum kokoh berhadapan dengan berbagai pengaruh negatif lainnya. Berbeda dengan mahasiswa yang cerdas dalam belajar, cerdas dalam bersikap dan punya komitmen kuat terhadap peraturan. Mereka tahu persis menjaga sikap dan perilaku sesuai dengan keberadaannya sebagai mahasiswa Fakultas Teologi. Perilaku tersebut dapat dikatakan sebagai penghayatan terhadap kepercayaan dan keyakinan kepada Tuhan yang memberi waktu dan kesempatan untuk belajar dan berperilaku sebagaimana mestinya. Jadi kecerdasan intelektual dimbangi dengan perilaku yang menunjang keberhasilannya, hal ini menunjuk pada kestabilan dalam kepribadiannya.

Selain realitas yang telah disebutkan di atas, ada juga realitas lainnya seperti ada mahasiswa yang tidak menunjukkan perilaku belajar dan berkomunikasi dengan cara-cara yang 
bertanggung-jawab. Ada mahasiswa yang melakukan kesalahan atau kekeliruan berulang-ulang. Kehadiran di kelas selalu tidak tepat waktu, tidak mengerjakan tugas dan selalu memiliki alasan yang dicari-cari. Ketika berkomunikasi dengan sesama mahasiswa tidak memberi penghargaan yang semestinya. Perilaku seperti ini dapat dikatakan sebagai gambaran dari pribadi yang belum dewasa dan tidak bertanggung-jawab. Keyakinan terhadap Tuhan masih dapat dikategorikan bersifat infantil. Keyakinan terhadap Tuhan tidak dilihat ada hubungannya dengan perilaku dan tanggung-jawab yang semestinya. Hal ini diduga ada kaitannya dengan pendidikan yang dimulai dalam keluarga mahasiswa tersebut. Keluarga merupakan tempat didikan pertama dan utama, yang berfungsi membentuk kepribadian dan perilaku mahasiswa, menyangkut penghargaan terhadap orang lain, maupun diri sendiri, serta keyakinan akan penyertaan Tuhan atas usaha dalam studi, bahkan seluruh hidup yang dijalaninya. Jika seorang mahasiswa dibentuk kebiasaan dan perilaku yang baik, menunjang keberhasilan studi dan hidupnya, maka dimana ia ada, apapun yang dikerjakannya selalu dilakukan dengan baik. Hal itu dilihat sebagai adanya kesediaan dan keterbukaan hati untuk bertindak sesuai dengan kehendak Yang Kudus yang member semangat dan dorongan untuk bertindak dan berlaku sesuai dengan nilai-nilai Kristiani.

Penulis berasumsi jika perkembangan kepercayaan mahasiswa sampai pada taraf secara baik, maka mahasiswa akan belajar dan bersikap baik, sesuai dengan motivasi dari dalam dirinya. Motivasi dari dalam diri memperkuat keyakinan diri untuk berusaha dengan sebaik mungkin. Jadi motivasi internal yang kuat, memperkuat self-efficacy untuk melaksanakan tugastugas belajar, sekalipun tugas belajar itu banyak. Dengan kata lain perkembangan kepercayaannya searah dengan tindakan atau aktifitasnya. Tetapi jika dikatakan bahwa perkembangan kepercayaan mahasiswa teologi sampai pada taraf yang baik, tetapi aktifitas belajar dan tindakannya tidak menggambarkan tingkat kepercayaannya, maka dapat dikatakan terjadi ambivalensi dalam diri mahasiswa tersebut. Ambivalensi terjadi bisa disebabkan karena ketahanan pribadi mahasiswa berada dalam keadaan rapuh. Ada masalah-masalah atau faktorfaktor lain yang dihadapi mahasiswa, tetapi mahasiswa tidak dapat menyelesaikan masalahnya dengan cerdas. Masalah-masalah yang dihadapi dirasakan terlalu berat sehingga membuat mahasiswa tidak berdaya mewujudkan harapan dalam sudinya secara baik. Jadi dapat dikatakan bahwa perkembangan kepercayaannya (psikologi agamanya) tidak mendukung psikologi 
pendidikannya. Diharapkan dari setiap mahasiswa teologi memiliki tingkat perkembangan kepercayaan yang setaraf dengan tingkatan perjuangan dalam studinya.

Fakultas Teologi menjadi tempat mahasiswa dibina menjadi bakal calon pelayan jemaat atau gereja dan masyarakat.Menjadi pelayan yang diutus oleh gereja, membutuhkan ketahanan iman atau keyakinan terhadap penyertaan Tuhan perjuangan untuk menggapai cita-cita setiap mahasiswa yang luhur. Mahasiswa dipersiapkan bukan saja dari sisi pengetahuan, tetapi juga menyangkut kepribadian termasuk didalamnya perilaku yang menunjang pencapaian cita-citanya sebagai pelayan. Dengan demikian dapat dikatakan bahwa perilaku kepercayaan atau keyakinan dan perilaku belajar dari mahasiswa yang sungguh-sungguh mau jadi pelayan teruji, atau dapat dibuktikan.

\section{Daftar Pustaka}

1. Cote, J.E. \& Levine, Ch (1977). Motivation, Learning Environtment and human capital acquisition: Toward an integrated paradigm of student development.Journal College Student Developmnent. Vol.38 (3) 229-242.

2. Meadow, Mary.J. \& Kahoe, Richard.D. (1984). Psychology of Religion, New York:Harper \&Row Publisher.

3. Shunk, D.H., Pintrich, P.R \& Meeca, J.L. (2008). Motivation: Theory, Research, and Aplication. Third Edition. New Jersey: Pearson Merril Prentice.

4. Suprantiknya, A.(ed). (1995). Tahap-tahap Perkembangan Kepercayaan Menurut James W.Fowler: Sebuah Gagasan Baru dalam Psikologi Agama. Yogyakarta: Kanisius.

5. Vallon, E.G., Reid,K.Umali, Chr.\& Pahlert. (2003/2004). An analysis of effect of self estem, social support and participation. Journal of College Student Retention 5(3). 